\title{
Two new freshwater crab species of the genus Nanhaipotamon Bott, 1968 (Crustacea, Decapoda, Potamidae) from Huizhou, Guangdong Province, southern China
}

\author{
CHAO HUANG ${ }^{*}$, SIYING MAO² \& HSI-TE SHIH $^{3 *}$ \\ ${ }^{1}$ Australian Museum, 1 William St, Sydney NSW 2010, Australia.

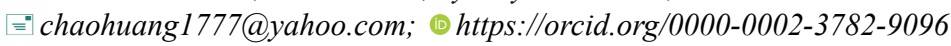 \\ ${ }^{2}$ Unaffiliated, Guangdong, China. ㄴ) https://orcid.org/0000-0001-5503-7474 \\ ${ }^{3}$ Department of Life Science and Research Center for Global Change, National Chung Hsing University, 250, Kuo Kuang Road, \\ Taichung 402, Taiwan. \\ "="htshih@dragon.nchu.edu.tw; ○ https://orcid.org/0000-0003-1317-8783 \\ ${ }^{*}$ Corresponding authors
}

\begin{abstract}
Two morphologically distinct new species of Nanhaipotamon Bott, 1968, are described from Huizhou, Guangdong Province, southern China. The smooth carapace and lack of flagellum on the third maxilliped exopod immediately separate $N$. incendium n. sp. from all other known Nanhaipotamon. It is also the first species of this genus to be recorded from a relatively high altitude of $700 \mathrm{~m}$ a.s.l. Nanhaipotamon aureomarginatum $\mathbf{n}$. sp. is externally much more typical of species of its genus but can be distinguished from congeners by its unique male first gonopod. The two new species are more or less sympatric with a morphological disparate congener, which we tentatively assign as $N$. aff. aculatum Dai, 1997 and $N$. aff. hongkongense (Shen, 1940), respectively, but with different habitats. A genetic analysis using the mitochondrial cytochrome oxidase subunit I shows that while the two new species are sufficiently distinct from other known species of Nanhaipotamon, they have extraordinarily close relationships with their respective sympatric congeners, which calls for further investigation. The ecology of these two new species are also noted.
\end{abstract}

Key words: cytochrome oxidase subunit I (COI), hillstream, new species, sympatric, systematics

\section{Introduction}

Guangdong Province in southern China is rich in freshwater crab species with some areas such as Huizhou City yet to be scientifically surveyed for them. New species from this province continue to be discovered at a fast rate (e.g. Huang et al. 2012, 2016, 2017, 2018a, b). The potamid genus Nanhaipotamon Bott, 1968, so far with 18 species, mainly occurs in the subtropical rainforests and agricultural lands of southern and eastern continental China, but is also present in the Taiwan main island and surrounding islands (Dai 1999, Shih et al. 2005, Huang et al. 2012, Huang et al. 2018b). Crabs of Nanhaipotamon are typically lowland species, usually found below $500 \mathrm{~m}$ a.s.1., that excavate burrows in the soft mud close to hillstreams (Dai 1999; Shih \& Ng 2011; Shih et al. 2011; Huang et al. 2012, 2018b; Lin et al. 2012, 2013). The name of the genus is derived from its main distribution, which is along the coastal areas of China facing the South China Sea ("Nanhai"). All known species of this genus share a similar bauplan: a bulging and generally smooth carapace typical of semiterrestrial potamids. The genus is pending revision as some "species" are indistinguishable externally and have very similar gonopodal morphology, while intraspecific variations are not well documented, causing problems in species identification (Huang et al. 2018b). Multiple insufficiently described species further compact this problem.

A few years ago, the first author (Chao Huang) noticed photos of a bright red freshwater crab from Huizhou on a social media post. The crab superficially resembled Nanhaipotamon, but its unique frontal regions of carapace were void of granules as typically seen in this genus (cf. Dai 1999). Several subsequent attempts to track down this animal were not successful. It was not until 2017 , that we were able to obtain a few specimens that were donated to us by 
Wei-Hang Wang, a researcher on jumping spiders, who had managed to find these crabs in dry shallow burrows at a relatively high altitude in Boluo County, Huizhou. After we collected additional material, this bright red crab was promptly identified as a new Nanhaipotamon species and is described here as Nanhaipotamon incendium $\mathbf{n}$. sp. On our second collection trip to Huizhou, we stumbled upon some mud holes next to a creek in another locality, from which we dug out some peculiar-looking crabs of Nanhaipotamon whose anterolateral margins and granules of the carapace front were strikingly bright golden. A series of specimens were thus collected for study. The unique morphology of the male first gonopods of these specimens indicates they belong to yet another undescribed species, which is described herein as Nanhaipotamon aureomarginatum $\mathbf{n}$. sp.

Notably, Nanhaipotamon incendium n. sp. is sympatric with $N$. aff. aculatum Dai, 1997, whereas Nanhaipotamon aureomarginatum $\mathbf{n}$. sp. is sympatric with $N$. aff. hongkongense (Shen, 1940). In both cases, the sympatric congeners occupy different habitats and are also morphologically distinct from each other. Genetic evidence shows that while the two new species are sufficiently distinct from other known species of Nanhaipotamon, they cannot be separated from their respective congeners using the mitochondrial cytochrome oxidase subunit I (COI). We speculate that strong divergent selection forces ("anti-cryptic speciation") are the main cause of this striking disparity between morphology and genetics (Bickford et al. 2007). This intriguing phenomenon calls for further genetic investigation which is regrettably inaccessible for us at the moment. The abovementioned $N$. aff. aculatum and $N$. aff. hongkongense, while morphologically similar, are genetically distinct and also come from different localities than the real $N$. aculatum and $N$. hongkongense and as such could not be identified with certainty.

\section{Material and methods}

Specimens were collected by hand from southern China and preserved in $75 \%$ ethanol since 2017 . These (type material) are now deposited in the Australian Museum, Sydney, Australia (AM); the Zoological Collection of the National Chung Hsing University, Taichung, Taiwan (NCHUZOOL); the Sun Yat-sen Museum of Biology, Sun Yat-sen University, Guangzhou, China (SYSBM); and the Zoological Reference Collection of the Lee Kong Chian Natural History Museum, National University of Singapore, Singapore (ZRC). Measurements, in millimetres, are of the carapace width and carapace length, respectively. Other abbreviations are as follows: G1, male first gonopod; G2, male second gonopod. The terminology used primarily follows that of Dai (1999) and Davie et al. (2015).

A portion of the COI gene, with 616-658 basepairs (bp), was amplified following Shih \& Poupin (2020), using the primers LCO1490, COL14, HCO2198 and COH6 (Folmer et al. 1994; Roman \& Palumbi 2004; Schubart \& Huber 2006), as well as a new designed internal primer ICOUB (5'-CCYCTTTCTACYATACTTCT-3'). Sequences of the different haplotypes were deposited into GenBank (accession numbers given in Table 1). Nanhaipotamon aculatum is only known from a single male specimen from Hong Kong. There is no precise locality data and also no DNA from the holotype to confirm the identity of this species. Our specimens from neighboring Shenzhen, however, show similar morphology to the illustrations in Dai (1997). We tentatively treat these Shenzhen specimens as belonging to this species. The case of Nanhaipotamon guangdongense Dai, 1997, is similar to the above, except the only male specimen is from Guangdong. We used a specimen from Gujing, Jiangmen of Guangdong Province to represent the species as that is where the holotype most likely came from (Huang et al. 2018b). Other COI sequences of Nanhaipotamon from southern China were also downloaded from GenBank for comparison, including N. macau Huang, Wong \& Ahyong, 2018 (MK226142) and N. wupingense Cheng, Yang, Zhong \& Li, 2003 (AB433569, AB470510, AB470511). Pairwise estimates of the Kimura (1980) 2-parameter distances for genetic diversities between specimens were calculated in MEGA (vers. 10.0.5, Kumar et al. 2018). 
TABLE 1. Specimens and the haplotypes of the COI gene from Nanhaipotamon species collected from southern China used in this study. See "Material and Methods" for abbreviations of museums and universities.

\begin{tabular}{|c|c|c|c|c|}
\hline Species & Locality & $\begin{array}{l}\text { Catalogue no. of SYSUM } \\
\text { (unless indicated) }\end{array}$ & $\begin{array}{l}\text { Sample } \\
\text { size }\end{array}$ & $\begin{array}{l}\text { GenBank } \\
\text { access. no. } \\
\text { COI }\end{array}$ \\
\hline \multirow[t]{5}{*}{ N. incendium n. sp. } & Guangdong: Huizhou & 001806 & 2 & $\begin{array}{l}\text { MZ662832, } \\
\text { MZ662833 }\end{array}$ \\
\hline & Guangdong: Huizhou & 001803 & 1 & MZ662834 \\
\hline & Guangdong: Huizhou & 001804 & 1 & MZ662835 \\
\hline & Guangdong: Huizhou & 001802 & 1 & MZ662836 \\
\hline & Guangdong: Huizhou & 001805 & 1 & MZ662837 \\
\hline \multirow[t]{3}{*}{ N. aff. aculatum } & Guangdong: Huizhou & 001779 & 1 & MZ662838 \\
\hline & Guangdong: Huizhou & 001778 & 1 & MZ662839 \\
\hline & Guangdong: Huizhou & 001776 & 1 & MZ662840 \\
\hline \multirow{5}{*}{$\begin{array}{l}\text { N. aureomarginatum } \\
\text { n. sp. }\end{array}$} & Guangdong: Huizhou & 001812 & 1 & MZ662841 \\
\hline & Guangdong: Huizhou & 001815 & 1 & MZ662842 \\
\hline & Guangdong: Huizhou & 001813 & 1 & MZ662843 \\
\hline & Guangdong: Huizhou & NCHUZOOL 17036 & 1 & MZ662844 \\
\hline & Guangdong: Huizhou & AM P.105615 & 1 & MZ662845 \\
\hline \multirow[t]{6}{*}{$N$. aff. hongkongense } & Guangdong: Huizhou & 001992 & 1 & MZ662846 \\
\hline & Guangdong: Huizhou & 001993 & 1 & MZ662847 \\
\hline & Guangdong: Huizhou & 001998 & 1 & MZ662848 \\
\hline & Guangdong: Huizhou & 001999 & 1 & MZ662849 \\
\hline & Guangdong: Shenzhen & 002001 & 1 & MZ662850 \\
\hline & Guangdong: Shenzhen & 002002 & 1 & MZ662851 \\
\hline \multirow[t]{4}{*}{ N. hongkongense } & $\begin{array}{l}\text { Hong Kong: New Territory: } \\
\text { Nai Chung stream }\end{array}$ & ZRC 1991.1776 (neotype) & 1 & $M Z 662852^{\mathrm{a}}$ \\
\hline & $\begin{array}{l}\text { Hong Kong: Hong Kong Island: } \\
\text { Wan Chai Gap; Tin Wan }\end{array}$ & $\begin{array}{l}\text { NCHUZOOL 17037, } \\
17038\end{array}$ & 2 & $\begin{array}{l}\text { MZ662853, } \\
\text { MZ662854 }\end{array}$ \\
\hline & $\begin{array}{l}\text { Hong Kong: Hong Kong Island: } \\
\text { Tin Wan }\end{array}$ & NCHUZOOL 17039 & 1 & MZ662855 \\
\hline & $\begin{array}{l}\text { Hong Kong: Hong Kong Island: } \\
\text { Tin Wan }\end{array}$ & NCHUZOOL 17040 & 1 & MZ662856 \\
\hline \multirow[t]{3}{*}{ N. aculatum } & Guangdong: Shenzhen & 001303 & 1 & MZ662857 \\
\hline & Guangdong: Shenzhen & 001028,001179 & 2 & $\begin{array}{l}\text { MZ662858, } \\
\text { MZ662859 }\end{array}$ \\
\hline & Guangdong: Dongguan & NCHUZOOL 13138 & 1 & AB433575 \\
\hline N. guangdongense & Guangdong: Jiangmen & 001141 & 1 & MZ662860 \\
\hline \multirow{4}{*}{$\begin{array}{l}\text { N. zhuhaiense Huang, } \\
\text { Huang \& Ng, } 2012\end{array}$} & Guangdong: Zhuhai & 001001 & 1 & MZ662861 \\
\hline & Guangdong: Zhuhai & 001249 & 1 & MZ662862 \\
\hline & Guangdong: Zhuhai & 001023 & 1 & MZ662863 \\
\hline & Guangdong: Zhuhai & 001015 & 1 & MZ662864 \\
\hline
\end{tabular}

${ }^{a}$ sequences are shorter and not included for further analyses (see DNA analyses and discussion). 


\title{
Taxonomy
}

\section{Family Potamidae Ortmann, 1896}

\author{
Subfamily Potamiscinae Bott, 1970
}

\section{Genus Nanhaipotamon Bott, 1968}

Type species. Potamon (Potamon) formosanum Parisi, 1916, by original designation; gender neuter.

\section{Nanhaipotamon incendium $\mathbf{n}$. sp.}

(Figs. 1-3, 7I, J, 8A)

urn:Isid:zoobank.org:act:60AD742A-6170-4790-8563-4CC10722CFA4

Type material. Holotype: SYSBM 001799, male $(31.3 \times 25.0 \mathrm{~mm})$, Boluo County [ca. $23.3^{\circ} \mathrm{N}, 114.3^{\circ} \mathrm{E}$ ], Huizhou City, Guangdong Province, China, shallow mud burrow, 700 m a.s.l., coll. C. Huang, August 2018.

Paratypes: SYSBM 001801, 001803, 001804, 3 males $(27.0 \times 21.6 \mathrm{~mm}, 25.4 \times 20.5 \mathrm{~mm}, 18.7 \times 15.3 \mathrm{~mm})$, same data as for holotype; SYSBM 001800, 001802, 2 females $(32.0 \times 25.0 \mathrm{~mm}, 29.4 \times 23.6 \mathrm{~mm})$, same data as for holotype; SYSBM 001805, male $(25.2 \times 20.2 \mathrm{~mm})$, Boluo County, Huizhou City, Guangdong Province, China, shallow mud burrow, 700 m a.s.l., coll. W.H. Wang, August 2017; SYSBM 001806, female $(27.9 \times 21.6 \mathrm{~mm})$, same data as above; NCHUZOOL 17034, male $(31.3 \times 25.0 \mathrm{~mm})$, Boluo County, Huizhou City, Guangdong Province, China, deep mud burrow with water at bottom, $700 \mathrm{~m}$ a.s.1., coll. C. Huang, November 2018; AM P.105614, male $(29.1 \times 23.8 \mathrm{~mm})$, Boluo County, Huizhou City, Guangdong Province, China, shallow mud burrow, $700 \mathrm{~m}$ a.s.l. coll., C. Huang, August 2018; AM P.105614, female $(32.7 \times 26.6 \mathrm{~mm})$, same data as above; ZRC 2021.0415, male $(25.8 \times 20.5 \mathrm{~mm})$, same data as above; ZRC 2021.0416 , female $(25.6 \times 21.0 \mathrm{~mm})$, same data as above.

Diagnosis. Carapace broader than long, regions indistinct (Fig. 1). Dorsal surface smooth, finely pitted, convex (Fig. 1). Anterolateral margins smooth, lined with numerous indistinct granules (Fig. 1). Posterolateral surfaces smooth (Fig. 1). Sub-orbital, sub-hepatic and pterygostomial regions clearly divided by sutures, with smooth and pitted surface (Fig. 2A). Maxilliped III exopod reaching to proximal one-fifth of merus, flagellum absent (Fig. 3A). G1 slender, reaching beyond pleonal locking tubercle almost up to suture between sternites IV/V in situ (Fig. 2D). G1 subterminal segment 2.6-2.7 $\times$ as long as terminal segment, tapering distally. G1 terminal segment relatively small, inverted foot-shaped; inner proximal margin strongly concave; inner distal margin almost straight to gently convex; apex acute, directed outward, orientation oblique to longitudinal axis of G1 (Figs. 3C-E, 7I, J). G2 subterminal segment 2.0-2.1 $\times$ as long as flagellum-like terminal segment $(n=3)$ (Fig. 3B).

Description. Carapace broader than long, width $1.2-1.3 \times$ length $(n=13)$, regions indistinct (Fig. 1). Dorsal surface smooth, finely pitted, convex (Fig. 1). Front deflexed, margin ridged in dorsal view (Fig. 1). Epigastric cristae smooth, very low and almost indistinct, separated from each other by narrow gap (Figs. 1, 2A). Postorbital cristae smooth, very low, laterally extended, almost fused with epigastric cristae and epibranchial teeth (Fig. 1). Branchial regions inflated; cervical grooves very shallow, inconspicuous; mesogastric region convex (Fig. 1). External orbital teeth blunt, triangular with gently convex outer margins, each separated from anterolateral margin by small gap (Figs. 1, 2A). Epibranchial teeth very small and inconspicuous (Figs. 1, 2A). Anterolateral margins smooth, lined with numerous indistinct granules (Fig. 1). Posterolateral surfaces smooth (Fig. 1). Orbits large, supraorbital and infraorbital margins ridged (Figs. 1, 2A). Sub-orbital, sub-hepatic and pterygostomial regions clearly divided by sutures, with smooth and pitted surface (Fig. 2A). Epistome median lobe broadly triangular, lateral margins almost straight (Fig. 2A).

Maxilliped III with merus subtrapezoidal, about as wide as long, median depression distinct; ischium subtrapezoidal, width about $0.9 \times$ length, with distinct median sulcus, with anterior mesial margin rounded; exopod reaching to proximal one-fifth of merus, flagellum absent (Fig. 3A).

Chelipeds (pereiopod I) unequal, relatively less inflated in females (Figs. 1, 3F-I). Merus trigonal in cross section, margins weakly crenulated, surfaces generally smooth (Figs. 1, 2A). Carpus with long, acute spine at innerdistal angle, spinule at base, surfaces generally smooth (Fig. 1). Major cheliped palm length about 1.1-1.2 $\times$ height in males $(n=5), 1.2-1.3 \times$ in females $(n=5)$; dactylus $1.0-1.1 \times$ palm length in males $(n=5)$ and females $(n=5)$ 


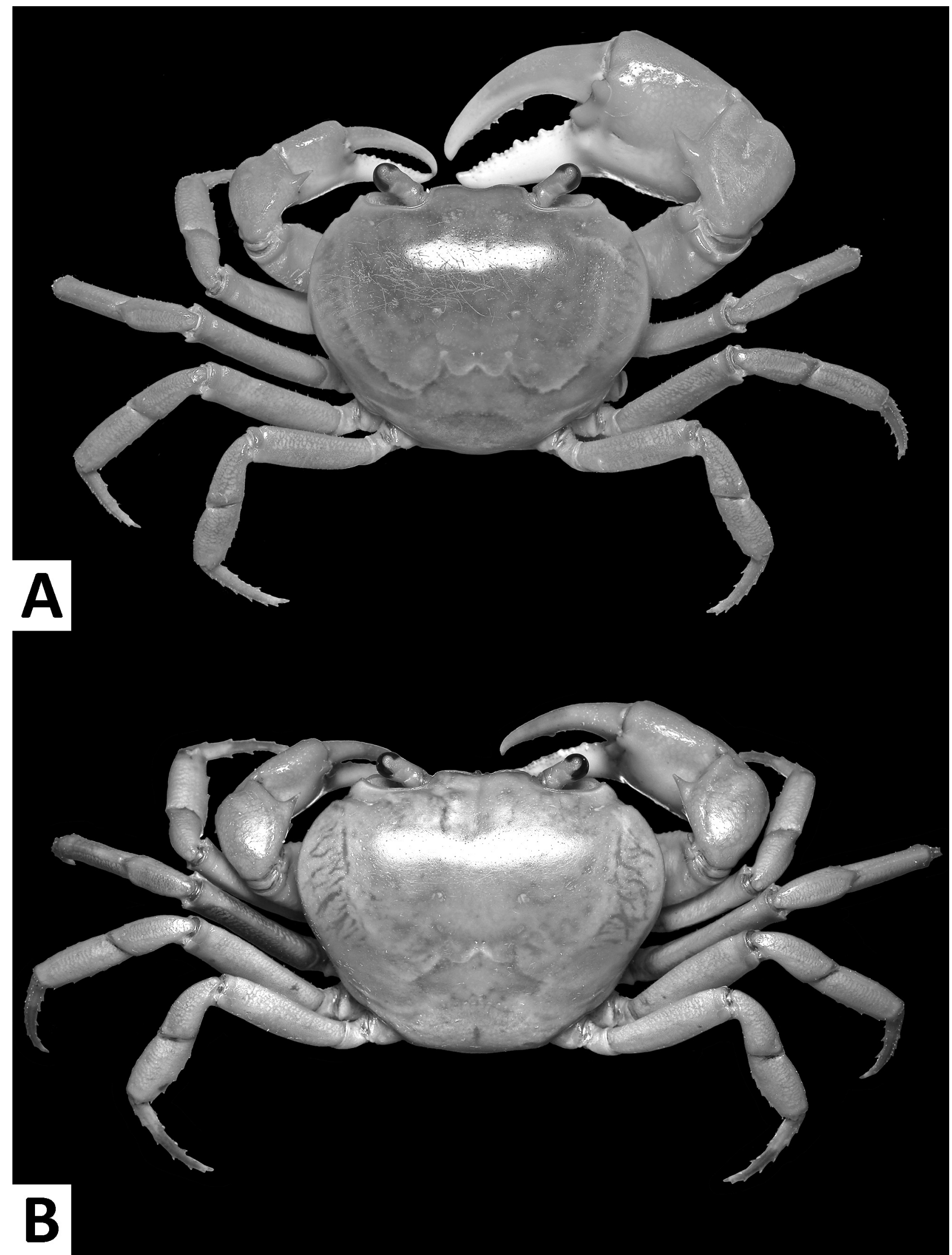

FIGURE 1. Dorsal habitus of Nanhaipotamon incendium n. sp. (A) male holotype $(31.3 \times 25.0$ mm), SYSBM 001799; (B) female paratype $(32.0 \times 25.0 \mathrm{~mm})$, SYSBM 001800 . 
(Fig. 3F-I). Palm surface generally smooth, pitted, inner posterior region slightly granulated. Dactylus curved, as long as pollex. Occlusal margin of fingers lined with blunt, round teeth; small gape when finger tips in contact (Fig. $3 \mathrm{~F}-\mathrm{I})$.

Ambulatory legs (pereiopods II-V) slender, with short and sparse setae. Pereiopod III merus $0.6-0.7 \times$ carapace length in males $(\mathrm{n}=5), 0.6-0.7$ in females $(\mathrm{n}=5)$. Pereiopods V propodus $2.3-2.4 \times$ as long as broad in males $(\mathrm{n}=$ 5), 2.3-2.5 in female $(\mathrm{n}=5)$, shorter than dactylus (Fig. 1).

Male thoracic sternum generally smooth, pitted; sternites I-IV relatively narrow, width $1.6 \times$ as length (Fig. 2B, C). Sternites I, II separated by ridge, fused as broadly triangular structure; sternites II, III separated by conspicuous transverse sulcus, reaching edge of sternum; sternites III, IV fused, without visible demarcation (Fig. 2B, C). Male sterno-pleonal cavity reaching anteriorly beyond level of posterior articular condyle of cheliped coxa (Fig. 2B-D); median longitudinal groove separating sternites VII, VIII deep (Fig. 2D). Male pleonal locking tubercles positioned at mid-length of sternite V (Fig. 2D). Adult female vulvae ovate, relatively large but not reaching sternites V or VII, positioned closely to one another, orientation oblique to longitudinal axis of sterno-pleonal cavity (Fig. 2F).

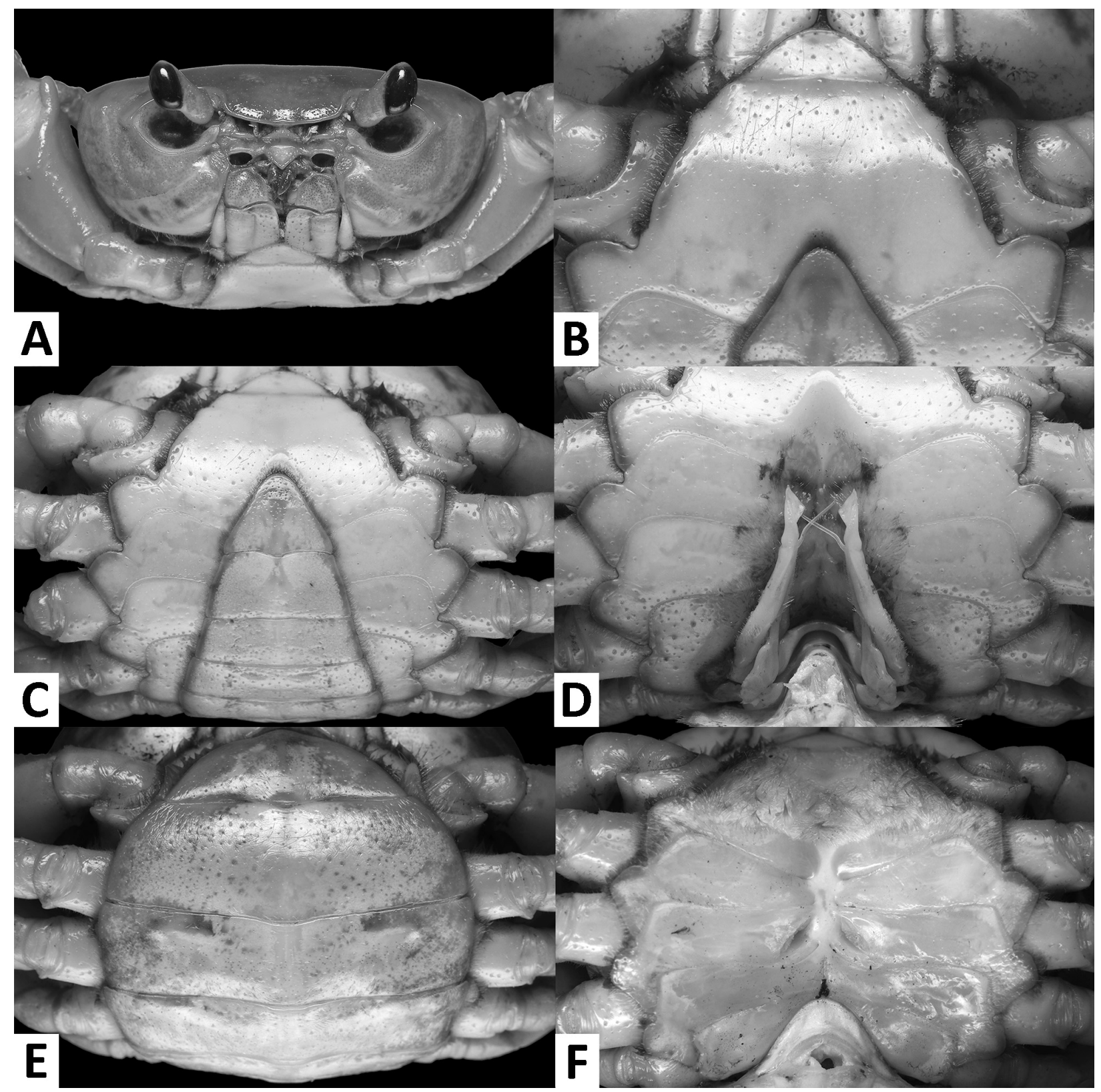

FIGURE 2. Nanhaipotamon incendium n. sp.: male holotype $(31.3 \times 25.0 \mathrm{~mm})$, SYSBM 001799 (A-D); female paratype $(32.0 \times 25.0 \mathrm{~mm})$, SYSBM $001800(\mathbf{E}, \mathbf{F})$. (A) cephalothorax, frontal view; (B) anterior thoracic sternum; (C) thoracic sternum, pleonites III-VI and telson; (D) sterno-pleonal cavity with G1 in situ, ventral view; (E) pleonites III-VI and telson; (F) sternum showing vulvae. 
Pleon and telson triangular in males (Fig. 2C) and broadly ovate in females (Fig. 2E). Male pleonites III-VI progressively narrower, lateral margins nearly straight; pleonite VI $2.2 \times$ as broad as long. Male telson $1.3 \times$ as broad as long, with blunt apex (Fig. 2C).

G1 slender, reaching beyond pleonal locking tubercle almost up to suture between sternites IV/V in situ (Fig. 2D). G1 subterminal segment 2.6-2.7 $\times$ as long as terminal segment $(n=3)$, tapering distally. G1 terminal segment relatively small, inverted foot-shaped; inner proximal margin strongly concave; inner distal margin almost straight to gently convex; apex acute, directed outward, orientation oblique to longitudinal axis of G1 (Figs. 3C-E, 7I, J). G2 subterminal segment 2.0-2.1 $\times$ as long as flagellum-like terminal segment $(\mathrm{n}=3)$ (Fig. 3B).

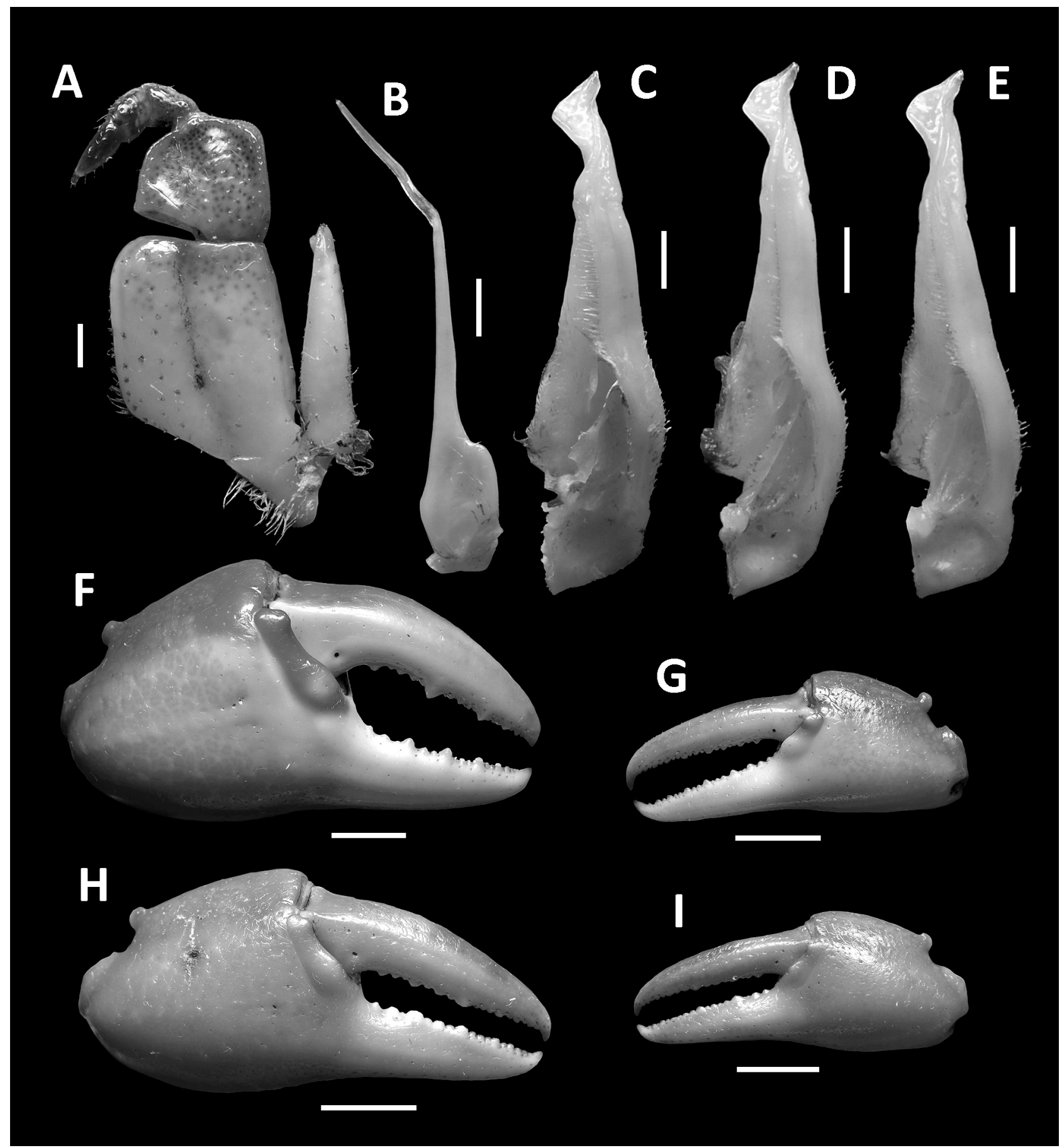

FIGURE 3. Nanhaipotamon incendium n. sp.: male holotype $(31.3 \times 25.0 \mathrm{~mm})$, SYSBM 001799 (A-C, F, G); male paratype $(27.0 \times 21.6 \mathrm{~mm})$, SYSBM $001801(\mathbf{D})$; male paratype $(25.4 \times 20.5 \mathrm{~mm})$, SYSBM $001803(\mathbf{E})$; female paratype $(32.0 \times 25.0$ mm), SYSBM 001800 (H, I). (A) left maxilliped III; (B) left G2, ventral view; (C-E) left G1, ventral view; (F, H) major cheliped; (G, I) minor cheliped. Scale bars: A-E = $1.0 \mathrm{~mm} ; \mathrm{F}-\mathrm{I}=5.0 \mathrm{~mm}$. 
Etymology. The specific name "incendium" means fire in Latin, which describes the live colouration of the species. The name thus is to be conceived as a noun in the nominative singular standing in apposition to the generic name.

Colour in life. Carapace, ambulatory legs and upper half of chelipeds generally bright red to orange, lower half of chelipeds white.

Habitat. Nanhaipotamon incendium $\mathbf{n}$. sp. is a semiterrestrial species that burrows in the forest floor of relatively high-altitude rainforests at around $700 \mathrm{~m}$ a.s.l., which is the highest recorded for this genus (Dai 1997, 1999). During summer, the rainforest not only receives a lot of rain but also abundant mist, which enables the crabs to freely roam on the forest floor. Crabs were collected from moist shallow burrows that do not reach the water table up to $50 \mathrm{~m}$ away from the nearest hillstream. In the winter when it is drier, however, the crabs burrow deep until they reach the water table. The once occupied shallow holes were found to be abandoned. Holes with fresh wet mud near the entrance were inaccessible to us due to the presence of roots and rocks, which made excavation nearly impossible. Immediately next to the hillstream, however, we found a few juveniles and a freshly molted adult male in mud holes under rocks. Longpotamon anyuanense (Dai, Zhou \& Peng, 1995) is a large aquatic species, which lives under rocks in the hillstreams and is sympatric with the new species. Nanhaipotamon aff. aculatum were found from the same mountain, but at lower altitudes typically around $100 \mathrm{~m}$ a.s.l. Only on one instance, the habitats of the two species seemed to overlap to some extent as they were found side by side in $500 \mathrm{~m}$ a.s.l. (W.-H. Wang, pers. comm.).

Remarks. The overall intraspecific morophological variation is low. Larger specimens of $N$. incendium $\mathbf{n}$. sp. tend to have a relatively wider carapace. The general shape of the G1 terminal segment in the new species seems to be stable, however, the inner distal margin varies from almost straight to gently convex (Fig. 3C-E). Nanhaipotamon incendium $\mathbf{n}$. sp. is a unique species within this genus in that it has smooth sub-orbital, sub-hepatic and pterygostomial regions (Fig. 2A) [vs. granulated or striated in all other congeners (Fig. 5A; Huang et al. 2018b: figs. 3B, 8B)], and the exopod of the maxilliped III is relatively shorter and completely lacks a flagellum (Fig. 3A) [vs. relatively longer exopod with flagellum in all other congeners (Fig. 6A; Huang et al. 2018b: fig. 5A)]. The relatively small G1 terminal segment of the new species is also unique within the genus (Figs. 3C-E, 7I, J) [vs. G1 terminal segment relatively large to very large in congeners (Figs. 6C-E, 7A-H; Huang et al. 2018b: figs. 5C-E, 7)]. The G1 of the new species is very distinct from the sympatric Nanhaipotamon aff. aculatum due to the same reason (Fig. 7D). In the field, the new species can readily be distinguished from the sympatric congener by its bright red to orange colouration (Fig. 8A) (vs. blue or light brown carapace in $N$. aff. aculatum; Fig. 8B). Nanhaipotamon cf. hongkongense from neighboring Shenzhen (Fig. 7E-G) can also be bright orange to red and may look similar to the new species, but the smoothness of the carapace frontal regions immediately separates the two species apart.

Conservation status. Nanhaipotamon incendium n. sp. is only known from a single collection point and is likely highly endemic. We do not know of any current threats to this species, though its bright colours make it a prime target for the pet trade. As the collection of freshwater crabs are not yet regulated by law in China, we choose to remain discreet about the exact locality of the new species.

\section{Nanhaipotamon aureomarginatum n. sp.}

(Figs. 4-6, 7K, L, 8C)

urn:lsid:zoobank.org:act:441A93FB-91A0-4FF3-9945-2EE9885B81BB

Type material. Holotype: SYSBM 001807, male $(37.7 \times 30.7 \mathrm{~mm})$, Huidong County [ca. $23.0^{\circ} \mathrm{N}, 114.7^{\circ} \mathrm{E}$ ], Huizhou City, Guangdong Province, China, burrow in soft mud near hillstream, $100 \mathrm{~m}$ a.s.l., coll. C. Huang, November 2018.

Paratypes: SYSBM 001809-001812, 4 males $(30.9 \times 25.3 \mathrm{~mm}, 29.1 \times 23.2 \mathrm{~mm}, 27.4 \times 22.3 \mathrm{~mm}, 24.7 \times 20.5$ $\mathrm{mm})$, same data as holotype; SYSBM 001808, 001813-001815, 4 females $(33.9 \times 28.4 \mathrm{~mm}, 29.6 \times 24.9 \mathrm{~mm}, 19.24$ $\times 16.1 \mathrm{~mm}, 13.5 \times 11.1 \mathrm{~mm})$, same data as holotype; NCHUZOOL 17035 , male $(26.5 \times 21.5 \mathrm{~mm})$, same data as holotype; NCHUZOOL 17036, female $(25.5 \times 20.8 \mathrm{~mm})$, same data as holotype; AM P.105615, male $(28.9 \times 23.2$ $\mathrm{mm})$, same data as holotype; AM P.105615, female $(17.9 \times 15.0 \mathrm{~mm})$, same data as holotype.

Diagnosis. Carapace broader than long, regions indistinct (Fig. 4). Dorsal surface generally smooth, pitted, convex, slightly rugose on anterolateral regions in smaller specimens (Fig. 4). Anterolateral margins cristate with fused granules, bent inward posteriorly (Fig. 4). Posterolateral surfaces with low, oblique striae converging posteriorly; granules scattered among striae, some merged together (Fig. 4). Sub-orbital, pterygostomial regions covered with 


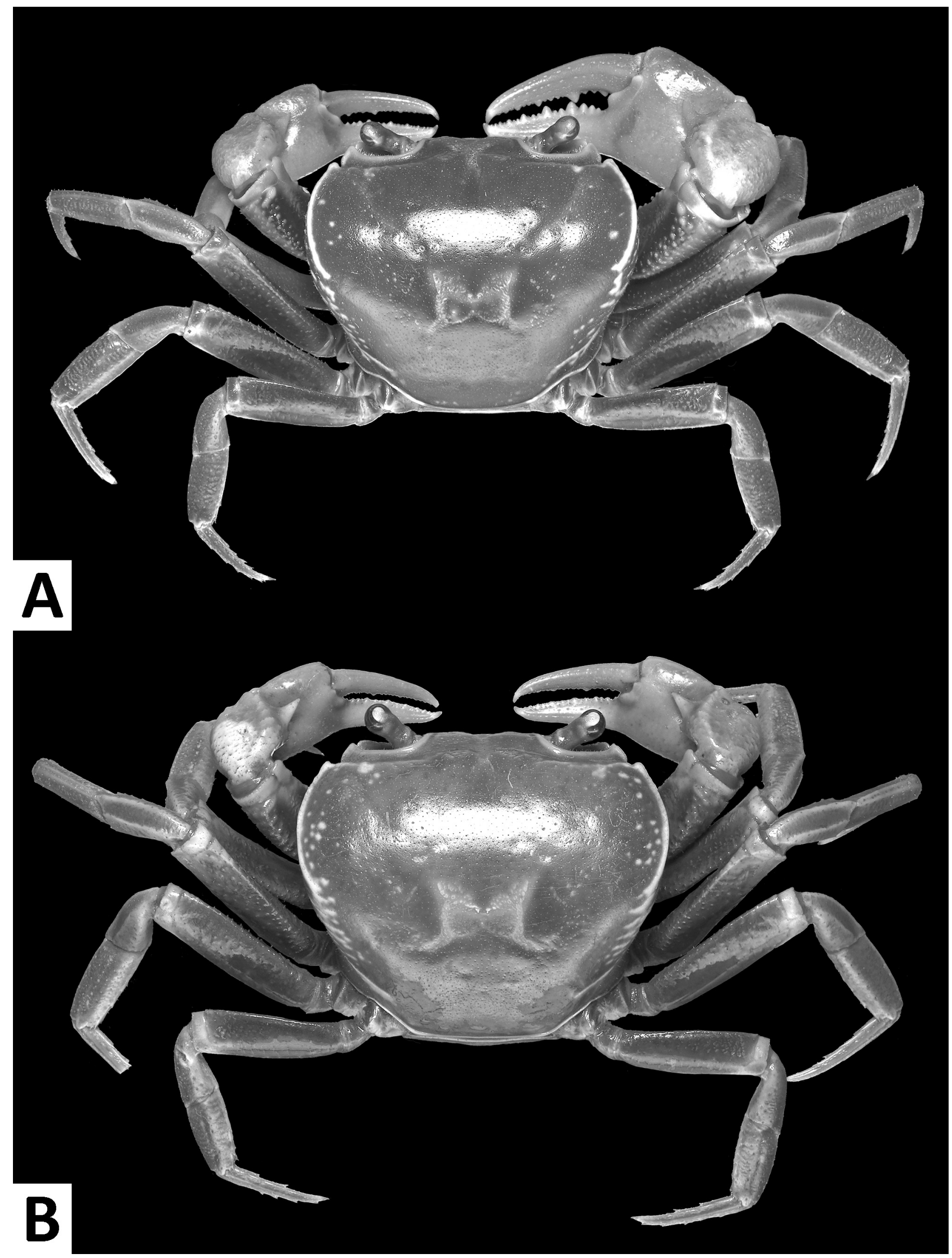

FIGURE 4. Dorsal habitus of Nanhaipotamon aureomarginatum n. sp.: (A) male holotype $(37.7 \times 30.7$ mm), SYSBM 001807; (B) female paratype $(33.9 \times 28.4 \mathrm{~mm})$, SYSBM 001808 . 
large round granules; sub-hepatic region with lines of fused smaller granules (Fig. 5A). Maxilliped III exopod reaching to proximal one-third of merus, with flagellum (Fig. 6A). G1 slender, reaching beyond suture between sternites IV/V in situ (Fig. 5D). G1 subterminal segment 2.1-2.2 $\times$ as long as terminal segment. G1 terminal segment large, duck head-shaped; mesial margin strongly convex; outer margin strongly concave; anterior margin almost straight, oblique to longitudinal axis of G1; apex pointing outwards (Figs. 6C-E, 7K, L). G2 subterminal segment $1.7-1.8 \times$ as long as flagellum-like terminal segment (Fig. 6B).

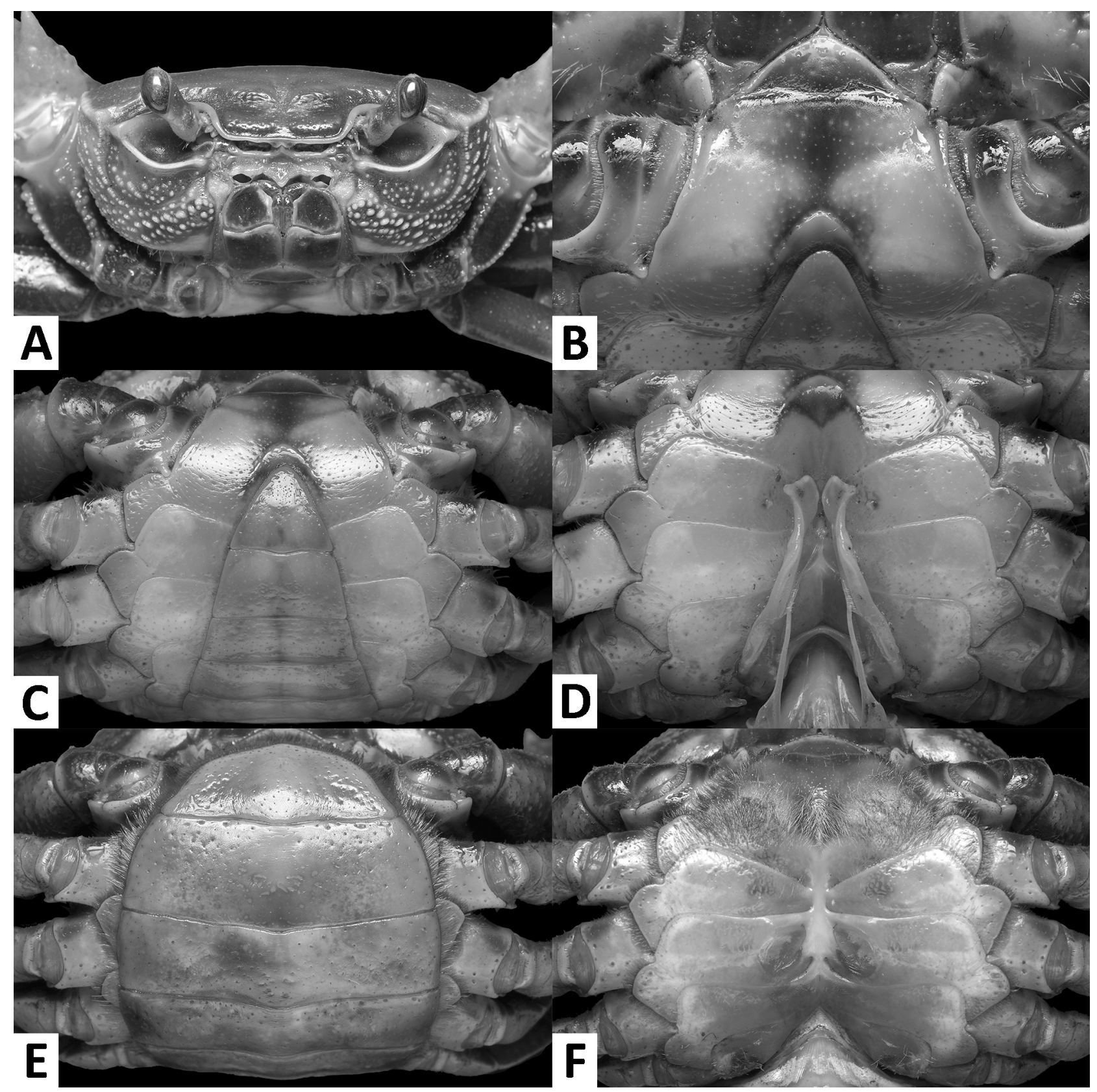

FIGURE 5. Nanhaipotamon aureomarginatum n. sp.: male holotype $(37.7 \times 30.7 \mathrm{~mm})$, SYSBM 001807 (A-D); female paratype $(33.9 \times 28.4 \mathrm{~mm})$, SYSBM 001808 (E, F). (A) cephalothorax, frontal view; (B) anterior thoracic sternum; (C) thoracic sternum, pleonites III-VI and telson; (D) sterno-pleonal cavity with G1 in situ, ventral view; (E) pleonites III-VI and telson; (F) sternum showing vulvae.

Description. Carapace broader than long, width $1.2-1.3 \times$ length $(\mathrm{n}=13)$, regions indistinct (Fig. 1). Dorsal surface generally smooth, pitted, convex, slightly rugose on anterolateral regions in smaller specimens (Fig. 4). Front deflexed, margin slightly ridged in dorsal view (Fig. 4). Epigastric cristae low, separated by a narrow gap (Fig. 4). Postorbital cristae prominent, laterally extended, almost fused with epigastric cristae and epibranchial teeth (Fig. 4). Branchial regions inflated; cervical grooves shallow; mesogastric region convex (Fig. 4). External orbital 
teeth blunt, triangular with gently convex outer margins, each separated from anterolateral margin by small gap (Figs. 4, 5A). Epibranchial teeth small, granular (Figs. 4, 5A). Anterolateral margins cristate with fused granules, bent inward posteriorly (Fig. 4). Posterolateral surfaces with low, oblique striae converging posteriorly; granules scattered among striae, some merged together (Fig. 4). Orbits large; supraorbital and infraorbital margins cristate (Figs. 4, 5A). Sub-orbital, pterygostomial regions covered with large round granules; sub-hepatic region with lines of fused smaller granules (Fig. 5A). Epistome median lobe broadly triangular, lateral margins sinuous (Fig. 5A).

Maxilliped III with merus subtrapezoidal, about as wide as long, median depression distinct; ischium; ischium subtrapezoidal, width about $0.7 \times$ length with distinct median sulcus, with anterior mesial margin rounded; exopod reaching to proximal one-third of merus, with flagellum (Fig. 6A).

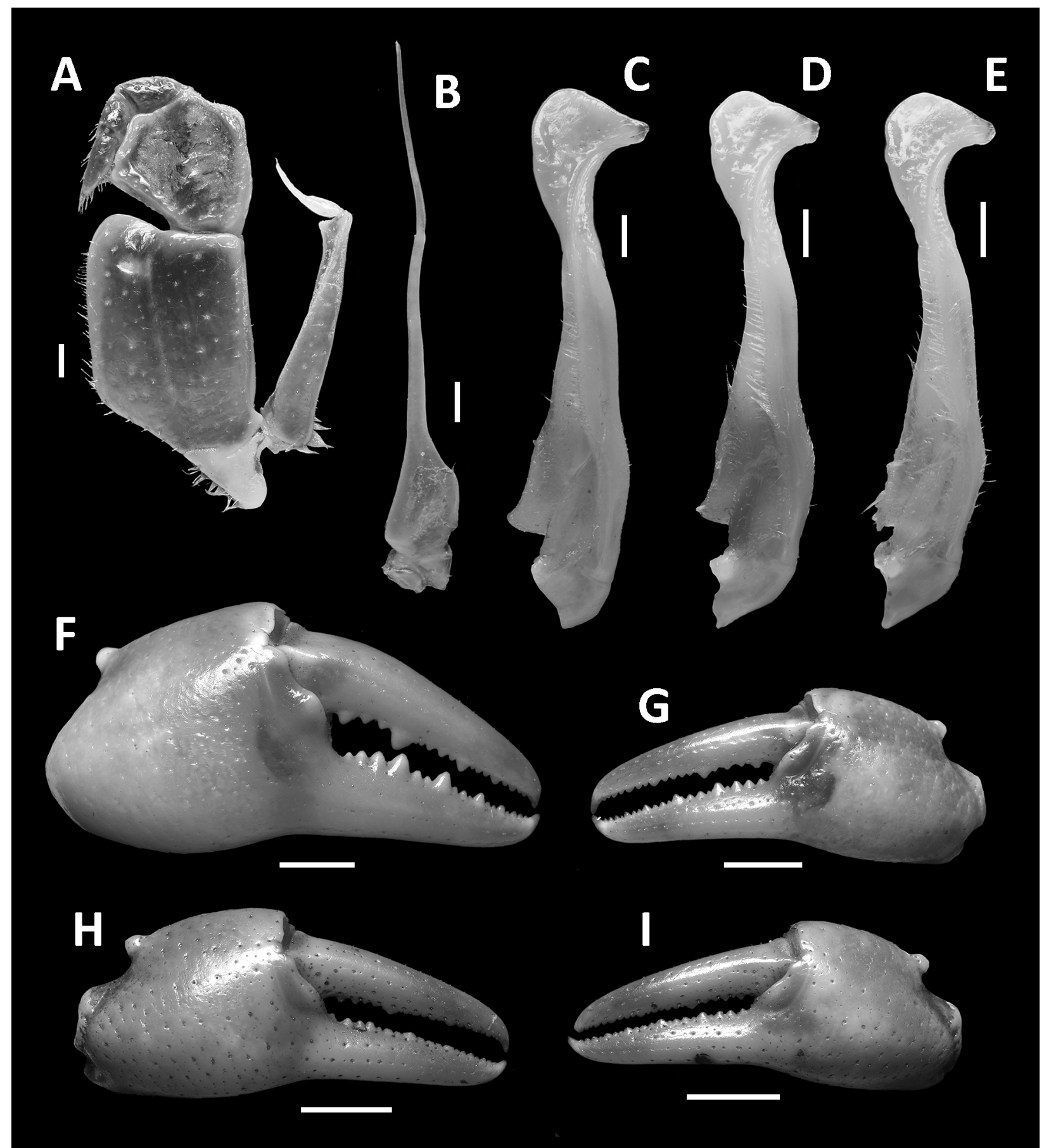

FIGURE 6. Nanhaipotamon aureomarginatum n. sp.: male holotype $(37.7 \times 30.7 \mathrm{~mm})$, SYSBM 001807 (A-C, F, G); male paratype $(30.9 \times 25.3)$, SYSBM 001809 (D); male paratype $(28.9 \times 23.2 \mathrm{~mm})$, AM $(\mathbf{E})$; female paratype $(33.9 \times 28.4 \mathrm{~mm})$, SYSBM 001808 (H, I). (A) left maxilliped III; (B) left G2, ventral view; (C-E) left G1, ventral view; (F, H) major cheliped; $(\mathbf{G}, \mathbf{I})$ minor cheliped. Scale bars: A-E $=1.0 \mathrm{~mm} ; \mathrm{F}-\mathrm{I}=5.0 \mathrm{~mm}$. 
Chelipeds (pereiopod I) unequal, relatively less inflated in females (Figs. 4, 6F-I). Merus trigonal in cross section, margins lined with granules, outer-dorsal surface rugose (Figs. 4, 5A). Carpus with long, acute spine at inner-distal angle, spinule at base, dorsal surface rugose (Fig. 4). Major cheliped palm length about 1.3-1.4 $\times$ height in males $(n=6), 1.4 \times$ in females $(n=3)$; dactylus about $1.0-1.1 \times$ palm length in both males $(n=6)$ and females $(n$ $=3$ ) (Fig. 6F-I). Palm surface pitted, dorsal surface rugose. Dactylus as long as pollex. Occlusal margin of fingers lined with irregular blunt teeth, slight gape when finger tips in contact (Fig. 6F-I).

Ambulatory legs (pereiopods II-V) slender, with short and sparse setae. Pereiopods III merus $0.7 \times$ carapace length in males $(\mathrm{n}=6), 0.6-0.7 \times$ in females $(\mathrm{n}=3)$. Pereiopods V propodus $2.0-2.4 \times$ as long as broad in males $(\mathrm{n}$ $=6), 2.2-2.3 \times$ in females $(n=3)$ (Fig. 4).

Male thoracic sternum generally smooth, pitted; sternites I-IV relatively narrow, width $1.4 \times$ as length (Fig. 5B, C). Sternites I, II fused, appearing broadly triangular; sternites II, III separated by shallow transverse sulcus, reaching edge of sternum; sternites III, IV fused, with barely visible demarcation (Fig. 5B, C). Male sterno-pleonal cavity reaching anteriorly to level of mid-length of cheliped coxa (Fig. 5B-D); median longitudinal groove separating sternites VII, VIII deep (Fig. 5D). Male pleonal locking tubercles positioned at mid-length of sternites V (Fig. 5D). Adult female vulvae ovate, relatively large but not reaching sternites V or VII ; positioned closely to one another, orientation oblique to longitudinal axis of sterno-pleonal cavity (Fig. 5F).

Pleon and telson triangular in males (Fig. 5C) and broadly ovate in females (Fig. 5E). Male pleonites III-VI progressively narrower, lateral margins nearly straight; pleonite VI $1.9 \times$ as broad as long. Male telson $1.2 \times$ as broad as long, with blunt apex (Fig. 5C).

G1 slender, reaching beyond suture between sternites IV/V in situ (Fig. 5D). G1 subterminal segment 2.1-2.2 $\times$ as long as terminal segment $(\mathrm{n}=3)$. G1 terminal segment large, duck head-shaped; mesial margin strongly convex; outer margin strongly concave; anterior margin almost straight, oblique to longitudinal axis of G1; apex pointing outwards (Figs. $6 \mathrm{C}-\mathrm{E}, 7 \mathrm{~K}, \mathrm{~L})$. G2 subterminal segment $1.7-1.8 \times$ as long as flagellum-like terminal segment $(\mathrm{n}=$ 3) (Fig. 6B).

Etymology. The specific name "aureomarginatum" alludes to the new species' golden-coloured anterolateral margins of the carapace. The name thus is to be conceived as an adjective in the nominative singular.

Colour in life. Colour variable. Carapace generally brown to dark purple; anterolateral margins, orbital margins, and granules and striae on frontal and lateral regions of carapace golden to bright orange. Ambulatory legs olive yellow to dark purple. Chelipeds light bluish grey to orange. Juveniles usually completely brown.

Habitat. Nanhaipotamon aureomarginatum n. sp. is a lowland semi-terrestrial species found at around $100 \mathrm{~m}$ a.s.l. While it is sympatric with Nanhaipotamon aff. hongkongense at the type locality, the two species seem to be ecologically distinct. The smaller sized $N$. aff. hongkongense digs in the gravelly soil at the water's edge next to the larger and fast flowing streams, whereas $N$. aureomarginatum $\mathbf{n}$. sp. is more terrestrial and prefers to burrow in soft mud near the smaller branches of the hillstream or seeps.

Remarks. The overall intraspecific morphological variation is low. The general shape of the G1 in $N$. aureomarginatum n. sp. seems to be quite stable (Fig. 6C-E). While externally a typical Nanhaipotamon, the proportionately large $\mathrm{G} 1$ terminal segment of $N$. aureomarginatum n. sp. (Figs. 6C-E, 7K, L) is unique amongst all congeners, with only the exceptions of $N$. macau and N. wupingense (Figs. 3C-E, 7I, J; Huang et al. 2018b). Nanhaipotamon aureomarginatum $\mathbf{n}$. sp. can be nevertheless differentiated from the latter two species by the higher and rounded inner distal margin of the G1 terminal segment (Fig. 6C-E, 7K, L) [vs. G1 terminal segment with inner distal margin lower and sinuous in N. macau (Huang et al. 2018b: fig. 6C) and N. wupingense (Huang et al. 2018b: fig. 6D)]. In the field, the new species can easily be separated with the sympatric $N$. aff. hongkongense by the live colouration (see "colour in life"; Fig. 8C) (vs. dark red to red in $N$. aff. hongkongense; Fig. 8D).

Conservation status. Nanhaipotamon aureomarginatum n. sp. is likely highly endemic. Its bright colours make it a prime target for collection for the pet trade. With this consideration, we choose to remain discreet about the exact locality of the new species. 


\section{DNA analyses and discussion}

The pairwise nucleotide divergences with K2P distance for the first main clade are given in Table 2. The divergences within the " $N$. incendium $+N$. aff. aculatum" and " $N$. aureomarginatum $+N$. aff. hongkongense" clades are $0.43 \%$ $(0-0.92 \%)$ and $0.85 \%(0-1.82 \%)$, respectively. The minimum interspecific divergences of the above two clades with other species/clades are $1.86 \%$ and $2.17 \%$, respectively. The sequence of the neotype of $N$. hongkongense (ZRC 1991.1776) obtained is short (295 bp), but it is still enough to confirm specimens from Hong Kong Island are conspecific (Table 2).
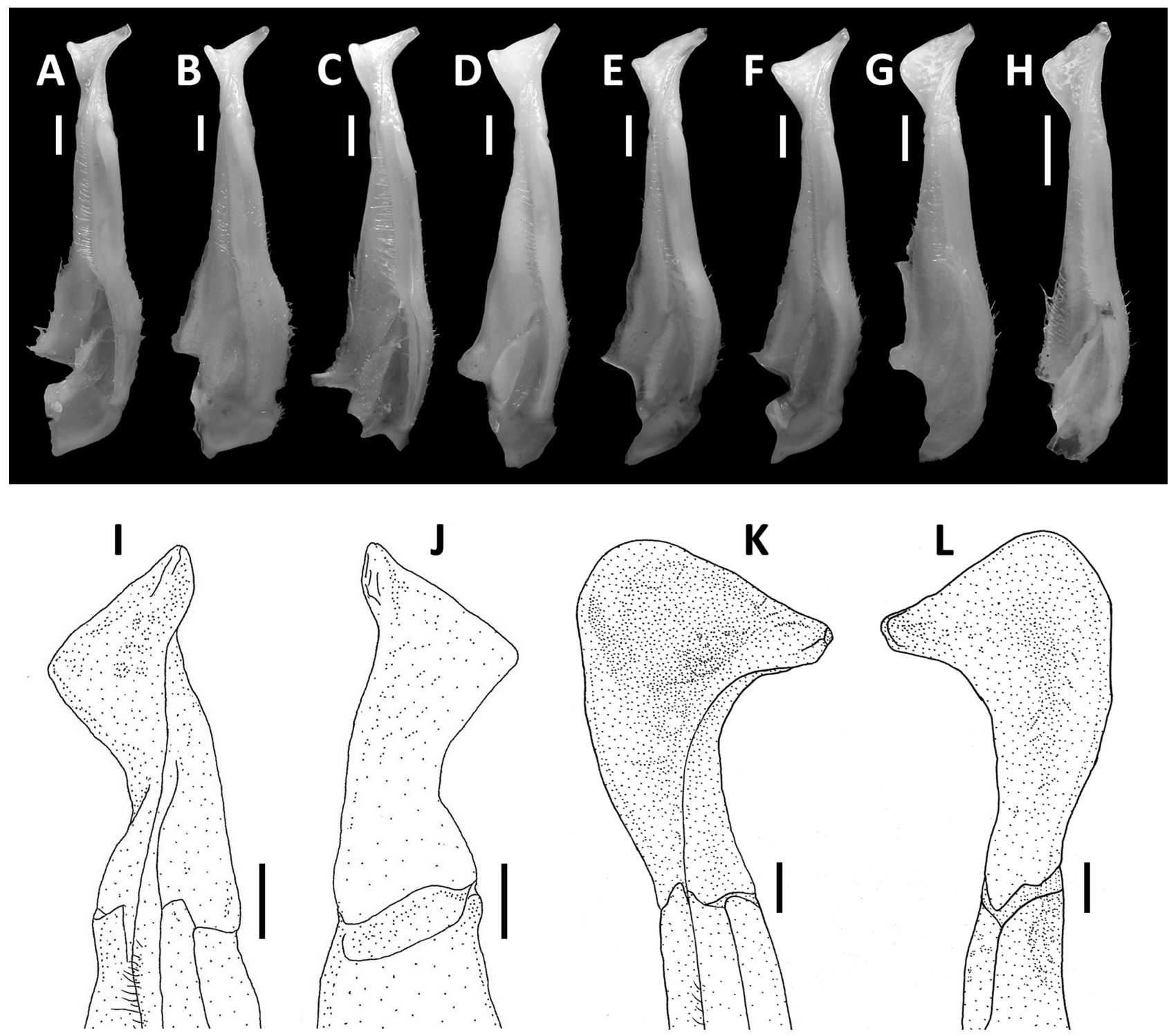

FIGURE 7. G1s of species of Nanhaipotamon compared in this study: Nanhaipotamon aculatum Dai, 1997 , male $(34.9 \times$ $28.3 \mathrm{~mm}$ ), SYSBM 001176, Bao'an, Shenzhen (A); Nanhaipotamon aculatum, male $(40.4 \times 31.5 \mathrm{~mm})$, SYSBM 001179, Bao'an, Shenzhen (B); Nanhaipotamon aculatum, male $(37.5 \times 30.0 \mathrm{~mm})$, SYSBM 001179, Shenzhen (C); Nanhaipotamon aff. aculatum, male (39.7 $\times 31.9$ mm), SYSBM 001776, Boluo, Huizhou (D); Nanhaipotamon cf. hongkongense (Shen, 1940), male $(32.0 \times 25.4 \mathrm{~mm})$, SYSBM 001780, Yantian, Shenzhen $(\mathbf{E})$; Nanhaipotamon cf. hongkongense, male $(31.0 \times 25.4 \mathrm{~mm}), \mathrm{SYSBM}$ 001781, Yantian, Shenzhen (F); Nanhaipotamon cf. hongkongense, male (28.0 $22.5 \mathrm{~mm})$, SYSBM 001782, Yantian, Shenzhen (G); Nanhaipotamon aff. hongkongense, male (20.5 × $16.2 \mathrm{~mm})$, SYSBM, Huidong, Huizhou (H); Nanhaipotamon incendium n. sp., male holotype $(31.3 \times 25.0 \mathrm{~mm})$, SYSBM 001799 (I, J); Nanhaipotamon aureomarginatum $\mathbf{n}$. sp., male holotype (37.7 $\times 30.7 \mathrm{~mm}$ ), SYSBM $001807(\mathbf{K}, \mathbf{L})$. (A-H) left G1, ventral view; (I, K) left G1 terminal segment, ventral view; (J, L) left G1 terminal segment, dorsal view. Scale bars: $\mathrm{A}-\mathrm{H}=1.0 \mathrm{~mm}$; $\mathrm{I}-\mathrm{L}=0.5 \mathrm{~mm}$. 


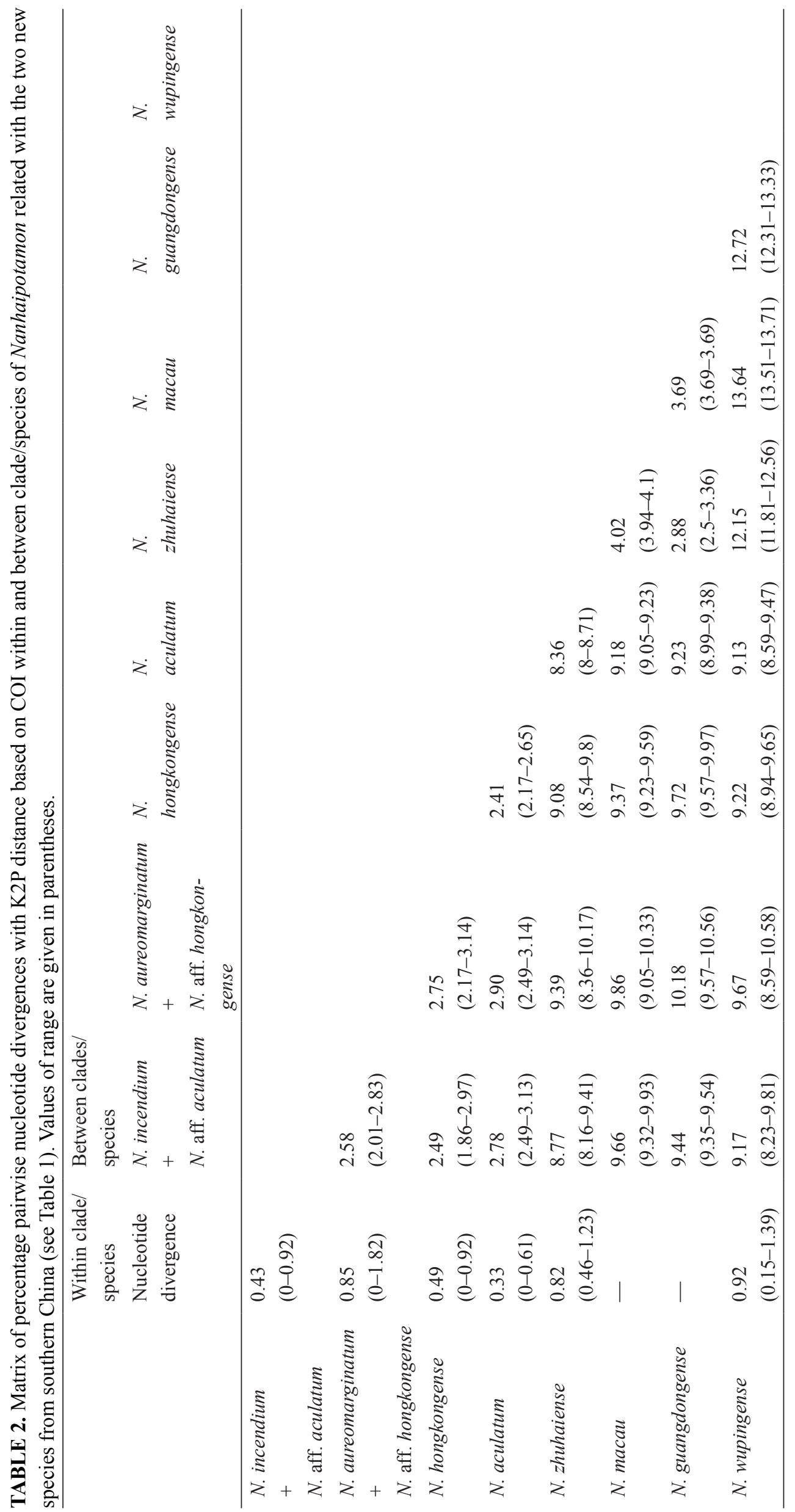


Based on the COI analyses, the clades " $N$. incendium $+N$. aff. aculatum" and " $N$. aureomarginatum $+N$. aff. hongkongense" are sufficiently divergent from other related congeners (Table 2; Shih et al. 2011: table 2) and other potamid genera (e.g., Chu et al. 2015: table 1; Huang et al. 2020: table 1) to be considered distinct lineages within Nanhaipotamon. The sympatric congeners $N$. aff. aculatum and $N$. aff. hongkongense are likely cryptic species but their exact identity and relationship with the two new species remain elusive. Nonetheless, the two new species can be genetically separated from all other related congeners included in the analysis. Nanhaipotamon aff. hongkongense is most similar with $N$. hongkongense from Hong Kong and $N$. cf. hongkongense from Shenzhen in morphology and colouration, but it is considerably smaller in size (Figs. 7H, 8D). It is nearly impossible to compare the G1 of different populations of the "hongkongense group" with any degree of confidence as the intraspecific variation between individuals from the same locality can be very large (Fig. 7E-G). In addition, a preliminary COI analysis (not shown) using a larger data set could not find monophyly in the different populations of $N$. hongkongense as identified by morphology from Hong Kong and Shenzhen, indicating the presence of cryptic speciation. On the other hand, $N$. aff. aculatum closely resembles $N$. aculatum in external and gonopodal morphology and colouration (Figs. 7D, 8B). Although $N$. aff. aculatum seems to have a slightly broader G1 terminal segment (Fig. 7D), there is also considerable intraspecific variation amongst $N$. aculatum to account for (Fig. 7A-C).

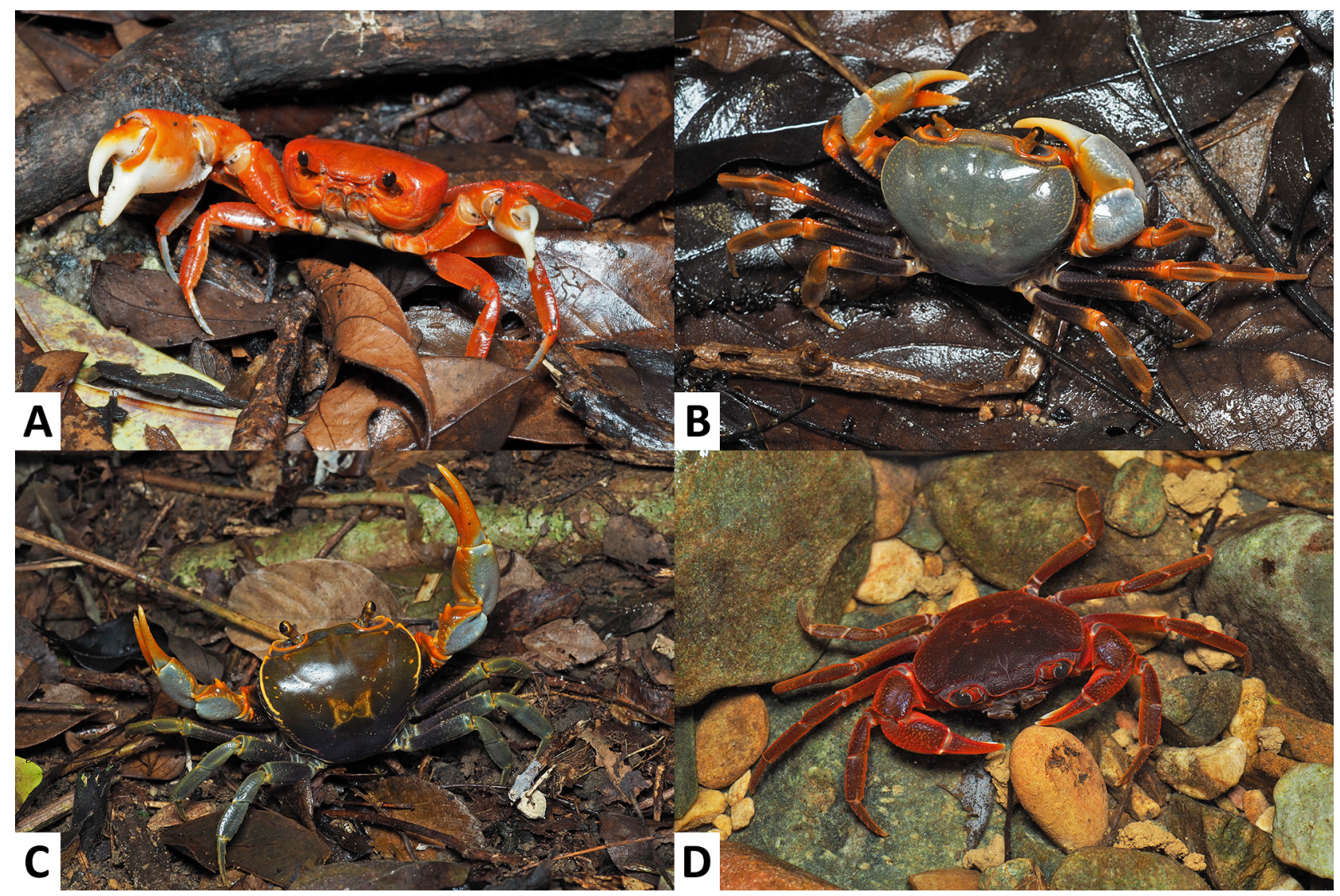

FIGURE 8. Colour in life. (A) Nanhaipotamon incendium n. sp., male, from type locality, specimen not collected; (B) Nanhaipotamon aff. aculatum Dai, 1997, male, from type locality of Nanhaipotamon incendium n. sp., specimen not collected; (C) Nanhaipotamon aureomarginatum n. sp., male holotype $(37.7 \times 30.7 \mathrm{~mm})$, SYSBM 001807, from type locality; (D) Nanhaipotamon aff. hongkongense (Shen, 1940), male, from type locality of Nanhaipotamon aureomarginatum n. sp., specimen not collected.

According to the present DNA analysis, the two new species are genetically indistinct from their respective sympatric congeners (Table 2). This intriguing result drastically conflicts the morphological evidence, which clearly separates the two new species from their respective sympatric congeners. This phenomenon is most likely caused by "anti-cryptic" speciation, where strong divergent selection forces caused rapid morphological divergence (Bickford et al. 2007; Chapple et al. 2011). Other cases that resemble "anti-cryptic" speciation can be found in other freshwater crabs, e.g., Geothelphusa Stimpson, 1858 from Taiwan (the G. olea Shy, Ng \& Yu, 1994 complex; Shih et al. 2007a), Somanniathelphusa Bott, 1968 (including S. amoyensis Naiyanetr \& Dai, 1997, S. taiwanensis Bott, 1968, 
and S. zhangpuensis Naiyanetr \& Dai, 1997) (Shih et al. 2007b, and Sundathelphusa Bott, 1969 from the Philippines [including S. boex Ng \& Sket, 1996, S. cavernicola (Takeda, 1983), and S. urichi Ng \& Sket, 1996] (Klaus et al. 2013); as well as marine crabs, e.g., Eriocheir De Haan, 1835 [in De Haan, 1833-1850] [between E. hepuensis Dai, 1991 and E. japonica (De Haan, 1835 [in De Haan, 1833-1850]) from Taiwan)] (J.-W. Xu et al. 2009; Ng et al. 2017); Helice De Haan, 1833 [in De Haan, 1833-1850] (including H. formosensis Rathbun, 1931, H. latimera Parisi, 1918, and H. tientsinensis Rathbun, 1931) (Shih \& Suzuki 2008; N.K. Ng et al. 2018), Gelasimus Latreille, 1817 [including G. borealis (Crane, 1975), G. dampieri (Crane, 1975), G. vocans (Linnaeus, 1758), and G. vomeris (McNeill, 1920)] (Shih et al. 2010), and Paraleptuca Bott, 1973 [between P. boninensis (Shih, Komai \& Liu, 2013) and P. crassipes (White, 1847), if only based on COI; Shih et al. 2013]. In the case of Helice formosensis, H. latimera and $H$. tientsinensis, the three species can not be separated by mitochondrial and nuclear markers $(12 \mathrm{~S}, 16 \mathrm{~S}$, COI, ITS-2 and 28S); and the intermediate morphological form of the latter two species has been found (J.-M. Xu et al. 2010), which suggests that, at least for $H$. latimera and $H$. tientsinensis, the observed morphological differences among them may only be intraspecific variation (N.K. Ng et al. 2018). In contrast, using an additional control region marker, Paraleptuca boninensis and P. crassipes can be genetically separated, supporting the morphological evidence (Shih et al. 2013). Similarly, using nuclear ITS-1 sequences, at least some species in the Geothelphusa olea complex and the Gelasimus vocans complex can be successfully separated (Chu et al. 2015; H.-T. Shih, unpublished data). Further studies using higher resolution of markers (e.g., control marker, ITS-1, ITS-2, etc.) are needed to reveal the genetic relations within the " $N$. incendium $+N$. aff. aculatum" and " $N$. aureomarginatum $+N$. aff. hongkongense" clades. Collections should also be carried out to further confirm whether any morphologically intermediate forms exist. As we can see, with cryptic speciation, "anti-cryptic" speciation, limited usable morphological characters and large intra-population and intra-species morphological variation, the genus Nanhaipotamon presents a challenge to conventional taxonomy and opportunity to better understand speciation and evolution.

\section{Acknowledgements}

This study was partially supported by a grant from the Ministry of Science and Technology (MOST 108-2313-B005-007-MY3), Executive Yuan, Taiwan, to HTS. We would like to thank Wei-Hang Wang for sharing with us the location of Nanhaipotamon incendium; Kingsley J. H. Wong for providing additional specimens from Hong Kong; and Peter K. L. Ng (ZRC) for the loaning of the neotype of $N$. hongkongense. We also acknowledge the reviewer Sameer Kumar Pati (Zoological Survey of India, India) for helping improve the manuscript.

\section{References}

Bickford, D., Lohman, D.J., Sodhi, N.S., Ng, P.K.L., Meier, R., Winker, K., Ingram, K. \& Das, I. (2007) Cryptic species as a window on diversity and conservation. Trends in Ecology and Evolution, 22, 148-155. https://doi.org/10.1016/j.tree.2006.11.004

Chapple, D.G., Bell, T.P., Chapple, S.N.J., Miller, K.A., Daugherty, C.H. \& Patterson, G.B. (2011) Phylogeography and taxonomic revision of the New Zealand cryptic skink (Oligosoma inconspicuum; Reptilia: Scincidae) species complex. Zootaxa, 2782 (1), 1-33. https://doi.org/10.11646/zootaxa.2782.1.1

Chu, K.H., Schubart, C.D., Shih, H.-T. \& Tsang, L.M. (2015) Genetic diversity and evolution of Brachyura. In: Castro, P., Davie, P.J.F., Guinot, D., Schram, F.R. \& von Vaupel Klein, J.C. (Eds.), Treatise on Zoology-Anatomy, Taxonomy, Biology-The Crustacea, Complementary to the Volumes Translated from the French of the Traite de Zoologie. 9 (C) (II). Decapoda: Brachyura. Part 2. Brill, Leiden, pp. 775-820. https://doi.org/10.1163/9789004190832_016

Dai, A.-Y. (1997) A revision of freshwater crabs of the genus Nanhaipotamon Bott, 1968 from China (Crustacea: Decapoda: Brachyura: Potamidae). Raffles Bulletin of Zoology, 45, 209-235.

Dai, A.-Y. (1999) Fauna Sinica. Arthropoda: Crustacea: Malacostraca: Decapoda: Parathelphusidae, Potamidae. Science Press, Beijing, China, 501 pp, 30 pls. [in Chinese]

Davie, P.J.F., Guinot, D. \& Ng, P. K.L. (2015) Anatomy and functional morphology of Brachyura. In: Castro, P., Davie, P. J. F., Guinot, D., Schram, F. R. \& von Vaupel Klein, J. C. (eds.), Treatise on Zoology-Anatomy, Taxonomy, Biology-The Crustacea, complementary to the volumes translated from the French of the Traité de Zoologie. Brill, Leiden 9(C)(I), Decapoda: Brachyura (Part 1), 11-163. 
https://doi.org/10.1163/9789004190832_004

Folmer, O., Black, M., Hoeh, W., Lutz, R. \& Vrijenhoek, R. (1994) DNA primers for amplification of mitochondrial cytochrome c oxidase subunit I from diverse metazoan invertebrates. Molecular Marine Biology and Biotechnology, 3, $294-299$.

Huang, C., Ahyong, S.T. \& Shih, H.-T. (2017) Cantopotamon: a new genus of freshwater crabs from Guangdong, China, with descriptions of four new species (Crustacea: Decapoda: Brachyura: Potamidae). Zoological Studies, 56, 41. https://doi.org/10.6620/ZS.2017.56-41

Huang, C., Huang, J.-R. \& Ng, P.K.L. (2012) A new species of Nanhaipotamon Bott, 1968 (Crustacea: Decapoda: Brachyura: Potamidae) from Zhuhai, Guangdong Province, China. Zootaxa, 3588 (1), 55-63. https://doi.org/10.11646/zootaxa.3588.1.2

Huang, C., Shih, H.-T. \& Ahyong, S.T. (2018a) Two new genera and two new species of narrow-range freshwater crabs from Guangdong, China (Decapoda: Brachyura: Potamidae). Journal of Crustacean Biology, 38, 614-624. https://doi.org/10.1093/jcbiol/ruy050

Huang, C, Shih, H.-T. \& Mao, S.Y. (2016) Yuebeipotamon calciatile, a new genus and new species of freshwater crab from southern China (Crustacea, Decapoda, Brachyura, Potamidae). ZooKeys, 615, 61-72. https://doi.org/10.3897/zookeys.615.9964

Huang, C., Wong, K.C. \& Ahyong, S.T. (2018b). The freshwater crabs of Macau, with the description of a new species of Nanhaipotamon Bott, 1968 and the redescription of Nanhaipotamon wupingense Cheng, Yang, Zhong \& Li, 2003 (Crustacea, Decapoda, Potamidae). ZooKeys, 810, 91-111. https://doi.org/10.3897/zookeys.810.30726

Huang, C., Wang, J. \& Shih, H.-T. (2020) A new genus and two new species of freshwater crab (Crustacea: Brachyura: Potamidae) with unusual coiled tip of male second gonopods from Yunnan, southwestern China. Zoological Studies, 59, 24. https://doi.org/10.6620/ZS.2020.59-24

Klaus, S., Mendoza, J.C.E., Huan, L.J., Martin, P., Meier, R. \& Yeo, D.C.J. (2013) Rapid evolution of troglomorphic characters suggests selection rather than neutral mutation as a driver of eye reduction in cave crabs. Biology Letters, 9, 20121098. https://doi.org/10.1098/rsbl.2012.1098

Kumar, S., Stecher, G., Li, M., Knyaz, C. \& Tamura, K. (2018) MEGA X: Molecular Evolutionary Genetics Analysis across computing platforms. Molecular Biology and Evolution, 35, 1547-1549. https://doi.org/10.1093/molbev/msy096

Lin, G.-H., Cheng, Y.-Z. \& Chen, S.-H. (2012) A new species of the genus Nanhaipotamon (Decapoda: Potamidae) from China. Chinese Journal of Parasitology and Parasitic Diseases, 30, 434-437. [in Chinese]

Lin, G.-H., Cheng, Y.-Z. \& Chen, S.-H. (2013) A new species of the genus Nanhaipotamon (Decapoda: Potamidae) serving as intermediate host of Paragonimus skrjabini. Chinese Journal of Parasitology and Parasitic Diseases, 31, 39-42. [in Chinese]

Ng, N.K., Naruse, T. \& Shih, H.-T. (2018) Helice epicure, a new species of varunid mud crab (Brachyura, Decapoda, Grapsoidea) from the Ryukyus, Japan. Zoological Studies, 57, 15.

Ng, P.K.L., Shih, H.-T., Ho, P.-H. \& Wang, C.-H. (2017) An updated annotated checklist of brachyuran crabs from Taiwan (Crustacea: Decapoda). Journal of the National Taiwan Museum, 70 (3/4), 1-208. https://doi.org/10.6532/JNTM.201712_70(3;4).01

Roman, J. \& Palumbi, S.R. (2004) A global invader at home: population structure of the green crab, Carcinus maenas, in Europe. Molecular Ecology, 13, 2891-2898. https://doi.org/10.1111/j.1365-294X.2004.02255.x

Schubart, C.D. \& Huber, M.G.J. (2006) Genetic comparisons of German populations of the stone crayfish, Austropotamobius torrentium (Crustacea: Astacidae). Bulletin Français de la Pêche et de la Pisciculture, 380-381, 1019-1028. https://doi.org/10.1051/kmae:2006008

Shih, H.-T., Chen, G.X. \& Wang, L.M. (2005). A new species of freshwater crab (Decapoda: Brachyura: Potamidae) from Dongyin Island, Matsu, Taiwan, defined by morphological and molecular characters, with notes on its biogeography. Journal of Natural History, 39, 2901-2911.

Shih, H.-T., Fang, S.-H. \& Ng, P.K.L. (2007b) Phylogeny of the freshwater crabs genus Somanniathelphusa Bott (Decapoda: Parathelphusidae) from Taiwan and the coastal regions of China, with notes on their biogeography. Invertebrate Systematics, 21, 29-37. https://doi.org/10.1071/IS06007

Shih, H.-T., Komai, T. \& Liu, M.-Y. (2013) A new species of fiddler crab from the Ogasawara (Bonin) Islands, Japan, separated from the widely-distributed sister species Uca (Paraleptuca) crassipes (White, 1847) (Crustacea: Decapoda: Brachyura: Ocypodidae). Zootaxa, 3746 (1), 175-193. https://doi.org/10.11646/zootaxa.3746.1.8

Shih, H.-T., Naruse, T. \& Ng, P.K.L. (2010) Uca jocelynae sp. nov., a new species of fiddler crab (Crustacea: Brachyura: Ocypodidae) from the Western Pacific. Zootaxa, 2337, 47-62. https://doi.org/10.5281/zenodo.193214

Shih, H.-T. \& Ng, P.K.L. (2011) Diversity and biogeography of freshwater crabs (Crustacea: Brachyura: Potamidae, Gecarcinucidae) from East Asia. Systematics and Biodiversity, 9, 1-16. https://doi.org/10.1080/14772000.2011.554457 
Shih, H.-T., Ng, P.K.L., Schubart, C.D. \& Chang, H.-W. (2007a) Phylogeny and phylogeography of the genus Geothelphusa (Crustacea: Decapoda, Brachyura, Potamidae) in southwestern Taiwan based on two mitochondrial genes. Zoological Science, Tokyo, 24, 57-66.

Shih, H.-T. \& Poupin, J. (2020) A new fiddler crab of Austruca Bott, 1973, closely related to A. perplexa (H. Milne Edwards, 1852) (Crustacea: Brachyura: Ocypodidae), from the South Pacific islands. Zoological Studies, 59, 26. https://doi.org/10.6620/ZS.2020.59-26

Shih, H.-T. \& Suzuki, H. (2008) Taxonomy, phylogeny, and biogeography of the endemic mudflat crab Helice/Chasmagnathus complex (Crustacea: Brachyura: Varunidae) from East Asia. Zoological Studies, 47, 114-125.

Shih, H.-T., Zhou, X.-M., Chen, G.-X., Chien, I.-C. \& Ng, P.K.L. (2011) Recent vicariant and dispersal events affecting the phylogeny and biogeography of East Asian freshwater crab genus Nanhaipotamon (Decapoda: Potamidae). Molecular Phylogenetics and Evolution, 58, 427-438. https://doi.org/10.1016/j.ympev.2010.11.013

Xu, J.-M., Yang, F. \& Sun, S.-C. (2010) Morphometrical studies on 10 populations of Helice tientsinensis and Helice latimera (Crustacea, Decapoda) from coasts of China. Acta Hydrobiologica Sinica, 34, 533-540. [in Chinese]

Xu, J.-W., Chan, T.-Y., Tsang, L.M. \& Chu, K.H. (2009) Phylogeography of the mitten crab Eriocheir sensu stricto in East Asia: Pleistocene isolation, population expansion and secondary contact. Molecular Phylogenetics and Evolution, 52, 45-56. https://doi.org/10.1016/j.ympev.2009.02.007 